\title{
EVOLUSI ILMU ARSITEKTUR
}

\author{
Nur Arief Hapsoro \\ Universitas Telkom, Program Studi Desain Interior \\ ariefhapsoro@telkomuniversity.ac.id
}

\begin{abstract}
The architectural field continues to evolve for the welfare of all living creatures. Along with the increasing complexity of human needs in a situation that is conducive, safe and comfortable, architecture becomes more multidisciplinary than ever. Issues relating to technology, ecology, energy, mitigation, and land limitations have the opportunity to become catalysts of architectural developments in the future. This study discusses advancements in architecture that would likely continue to evolve in the future.
\end{abstract}

Key Words: architecture, future, chronological, predictive

\begin{abstract}
Abstrak. Bidang arsitektur terus berkembang untuk kesejahteraan semua mahluk hidup. Bersamaan dengan meningkatnya kompleksitas kebutuhan manusia akan situasi yang kondusif, aman dan nyaman, arsitektur menjadi lebih multi-disiplin daripada sebelumnya. Isu-isu yang berkaitan dengan teknologi, ekologi, energi, mitigasi, dan keterbatasan lahan berpeluang menjadi katalisator perkembangan arsitektur di masa mendatang. Studi ini membahas kemajuan di bidang arsitektur yang kelak berpeluang terus berkembang di masa depan.
\end{abstract}

Kata Kunci : arsitektur, masa depan, kronologis, prediktif

\section{PENDAHULUAN}

Dalam makna sempit, arsitektur diartikan sebagai ilmu dan seni perencanaan dan perancangan bangunan. Sedangkan makna arsitektur sendiri dalam arti luas adalah ilmu dan seni perencanaan dan perancangan lingkungan binaan (artefak), mulai dari lingkup mikro (perencanaan dan perancangan bangunan, interior, perabot, dan produk), hingga lingkup makro (perencaan dan perancangan kota, kawasan, lingkungan, dan lansekap). Kata "arsitektur" sering juga dimaknai dalam pengertian lain untuk menggantikan istilah "hasil proses perancangan" (http://ft.uajy.ac.id diakses pada 16/12/2018).

Bidang arsitektur terus berkembang untuk kesejahteraan semua mahluk hidup. Pengertian arsitektur sendiri juga mengalami evolusi menjadi semakin kompleks, tidak hanya mencakup ilmu atau studi rancang-bangun. Pada masa sekarang, kata arsitektur jadi sering digunakan oleh disiplin ilmu lain untuk merepresentasikan sebuah sistem yang kompleks.

Sebagai sebuah ilmu, arsitektur selalu terkait dengan berbagai bidang ilmu lainnya. Karena merupakan ilmu perencanaan dan perancangan lingkungan binaan yang menjadi wadah bagi kegiatan manusia, maka arsitektur tidak dapat dilepaskan dari kaidah berbagai ilmu yang menyangkut aspek humanis, seperti psikologi, sosiologi, antropologi, filsafat, ergonomi, dan ekonomi, seperti kata Vitruvius, "Arsitektur adalah ilmu yang terlahir dari ilmuilmu lainnya, dan dilengkapi dengan proses pembelajaran: dibantu dengan penilaian terhadap karya tersebut sebagai karya seni". Perwujudan hasil karya arsitektur merupakan penerapan kaidah berbagai ilmu yang menyangkut aspek humanis tersebut. Bersamaan dengan meningkatnya kompleksitas kebutuhan manusia akan situasi kondusif, aman dan nyaman, arsitektur menjadi lebih multi-disiplin daripada sebelumnya. Sekarang ini arsitektur membutuhkan sekumpulan profesional dalam pengerjaannya. Inilah keadaan bidang arsitektur sekarang ini dan diprediksi akan berkembang terus menjadi bidang ilmu yang semakin kompleks di masa depan. Isu-isu yang berkaitan dengan teknologi, ekologi, energi, mitigasi, dan keterbatasan lahan ditengarai menjadi katalisator perkembangan arsitektur di masa mendatang. Studi ini akan membahas perkembangan arsitektur di masa depan yang disajikan secara diakronik maupun sinkronik. 


\section{METODOLOGI}

Pada tahap pengumpulan data dilakukan dengan literature review. Pada tahapan analisis data, menggunakan metode analisis kualitatif deskriptif, kemudian dijabarkan berdasarkan kronologis. Hingga akhirnya setelah dianalisis, langkah berikutnya disimpulkan menggunakan metode kualitatif prediktif.

\section{HASIL DAN PEMBAHASAN}

\section{Napak Tilas Dunia Arsitektur}

Arsitektur prasejarah dan primitif merupakan tahap awal pergumulan antara cara dan kebutuhan. Manusia kemudian berpikir lebih kritis dan pengetahuan mulai terbentuk melalui kebiasaan, yang diturunkan melalui tradisi lisan ke dalam berbagai bentuk praktik. Arsitektur berkembang dari kebiasaan menjadi ketrampilan. Seorang arsitek pada saat itu hanyalah sematamata melanjutkan tradisi. Permukiman manusia di masa lalu pada dasarnya bersifat rural, kemudian berkembang menjadi masyarakat urban. Kompleksitas bangunan dan tipologinya juga meningkat. Teknologi pembangunan infrastruktur seperti jalan dan jembatan pun berkembang. Meskipun, arsitektur religius tetap memegang peranan penting di dalam masyarakat, namun tipologi bangunan baru seperti sekolah, rumah sakit, dan sarana rekreasi mulai muncul.

Di periode Klasik hingga Abad Pertengahan Eropa, bangunan tidak lagi hasil karya dari arsitekarsitek individual, melainkan asosiasi profesi yang dibentuk oleh para ahli keterampilan bangunan untuk mengorganisasi proyek. Pada masa Pencerahan, pembangunan didelegasikan kepada arsitek-arsitek individual sebagai contoh: Michaelangelo, Donatello Bramante, Leonardo da Vinci, Ralphael, dsb. Namun, belum ada pembagian tugas yang jelas antara seniman, arsitek, maupun insinyur atau profesi lain yang berhubungan. Pada tahap ini, seorang seniman dapat menguasai banyak bidang keilmuan (Leonardo da Vinci mampu menguasai seni lukis, patung, arsitektur, sains, musik, matematika, insinyur, literatur, anatomi, geologi, astronomi, botani, sejarah, sastra, dan kartografi). Seorang seniman dapat pula merancang jembatan karena penghitungan struktur di dalamnya masih bersifat umum.

Bersamaan dengan penggabungan pengetahuan dari berbagai bidang ilmu, munculnya material bangunan baru, serta perkembangan teknologi, paradigma seorang arsitek mulai bergeser dari aspek teknis bangunan menuju ke estetika. Revolusi Industri berhasil memangkas biaya proses industri menjadi jauh lebih terjangkau, sehingga estetika menjadi ukuran yang dapat dicapai oleh kaum proletar. Produkproduk berornamen artistik yang dulunya terbatas dalam lingkup keterampilan yang mahal, menjadi terjangkau melalui produksi massal. Produkproduk tersebut tidak lagi memiliki makna dalam ekspresi dari sebuah proses produksi. Ketidakpuasan terhadap keadaan demikian pada awal abad ke-20 melahirkan pemikiran-pemikiran yang mendasari Arsitektur Modern (Jencks. 1960).

Salah satu inspirasi pemikiran tentang Arsitektur Modern, adalah dari Deutscher Werkbund (didirikan tahun 1907) yang memproduksi obyek-obyek buatan mesin dengan kualitas yang lebih baik dan merupakan awal lahirnya profesi dalam bidang desain industri. Setelah itu, sekolah Bauhaus (didirikan tahun 1919) yang mengesampingkan sejarah dan memilih melihat arsitektur sebagai sintesa seni, ketrampilan, dan teknologi. Arsitektur Modern bukan sekedar gaya baru dari arsitektur tetapi ini juga merupakan gambaran paradigma baru tentang sebuah bangunan (Jencks. 1960). Arsitektur modern lebih menekankan fungsi daripada pengimitasian alam ataupun estetika sebuah karya. Ciri khas bangunan ini adalah sedikitnya bahkan tidak adanya ornamen pada bangunan; bersifat minimalis; menekankan fungsi ruang; menggunakan material buatan manusia seperti logam dan beton. Arsitek kemudian menjadi sosok penting dan dijuluki sebagai "master". Kemudian arsitektur modern masuk ke dalam lingkup produksi masal karena kesederhanaannya dan faktor ekonomi (Jencks. 1960).

Namun, masyarakat umum merasakan adanya penurunan kualitas dalam arsitektur modern pada tahun 1960-an. Arsitek menjawabnya melalui Arsitektur Post-Modern (Jencks. 1960). Arsitektur Postmodern lebih sering 
dikenal sebagai sebuah gerakan arsitektur yang menentang arsitektur modern yang dianggap membosankan. Arsitektur ini juga disebut sebagai sebuah gerakan mengembalikan ornamen kepada seni bangunan. Bangunan postmodern ini seringkali mengejutkan orang yang melihat karena jauh berbeda dari bangunan-bangunan yang dikenal selama ini. Bentuk dari arsitektur postmodern tidak memiliki pakem yang standard atau formal. Arsitektur ini mengadopsi berbagai jenis estetika dari berbagai teknik arsitektur yang ada untuk mendapatkan kesan unik (Jencks. 1960).

\section{Arsitektur Hari Ini}

Bersamaan dengan meningkatnya kompleksitas kebutuhan manusia akan situasi kondusif, aman dan nyaman, arsitektur menjadi lebih multi-disiplin daripada sebelumnya sehingga membutuhkan sekelompok profesional dalam pengerjaannya. Pada masa sekarang, bidang karya arsitektural relatif sangat luas. Seorang arsitek dapat berperan di dalam mendukung perencanaan kota (urban planning), perancangan kota (urban design), perencanaan dan perancangan lingkungan/kawasan, perencanaan dan perancangan bangunan, perancangan interior (ruang dalam) bangunan, perancangan lansekap, perancangan mebel, pelaksana pembangunan (kontraktor), perusahaan perabot (meubel), surveyor dan/atau estimator, tenaga pendidik, peneliti, di dalam industri bahan bangunan, dan berperan di dalam bidang jasa konstruksi lain. Isuisu yang menjadi perhatian utama bidang arsitektur saat ini dan berpeluang hingga beberapa dekade ke depan adalah tentang kaitannya dengan teknologi, ekologi, energi, mitigasi, dan keterbatasan lahan. Perkembangan informasi dan teknologi terkini bahkan secara dramatis telah mengubah segalanya. Namun, seberapapun perubahan itu telah terjadi, kondisi alam dan lingkungan masih memiliki pengaruh besar pada cara hidup manusia.

\section{Masa Depan Arsitektur}

Manusia selalu berhadapan dengan perubahan di lingkungan mereka. Orang-orang dan cara hidupnya juga telah berubah dari waktu ke waktu (Idham, 2016). Perkembangan teknologi dan pengetahuan menyebabkan perubahan segala aspek kehidupan manusia, termasuk di bidang arsitektur. Berikut deskripsi kemajuan di bidang arsitektur yang kelak akan berpeluang terus berkembang di masa depan.

\section{Smart Building}

Seiring dengan kemajuan teknologi internet, adanya big data, cloud computing (Plageras, AP. Et al. 2017), BIM (Volkov, dan Batov. 2015) kebutuhan akan sebuah hunian dengan dukungan teknologi informasi (TI) yang modern akan semakin meningkat. Berpijak dari kebutuhan tersebut, muncullah konsep sistem bangunan pintar atau yang sering disebut dengan smart building. Konsep smart building mengoptimalkan sebuah bangunan dengan penggunaan teknologi modern tingkat tinggi seperti menggunakan PLC (programmable logic controllers) yang kemudian dihubungkan pada beberapa komponen lain (sensor) yang digunakan untuk mengendalikan hampir semua bagian dari bangunan. Sebagian besar kegiatan pengguna bangunan akan bisa dilakukan secara otomatis tanpa campur tangan manusia. Ini tentu sesuai dengan prinsip dan tujuan dari smart building itu sendiri, yaitu mengupayakan sebuah bangunan yang terjaga akan kemudahan, kenyamanan, keamanan, dan juga penghematannya (https://www.rumahku.com diakses pada 19/12/2018).

Dalam perkembangan lebih lanjut, smart building menjadi salah satu bagian di sebuah kesatuan sistem besar, yaitu Smart City. Komponen lain dari konsep Smart City adalah Smart Grid, Smart Citizens, Smart Security, Smart Infrastructure, Smart Technology, etc (Suciu, Et al. 2013. dan, Kim, Ramos, and Mohammed. 2017). Apabila masing-masing komponen tersebut dapat menjalankan tugasnya masing-masing dengan baik, maka terciplah sebuah Smart City yang kompak dan efisien.

\section{Algorithmic Architecture}

Arsitektur telah mengalami perubahan cara berpikir untuk mendapatkan suatu desain. Awalnya desain didapatkan dengan memakai alat manual hingga menjadi desain bentuk yang berbasis komputer. Perubahan ini, walaupun 
mengesankan, belum mencapai potensi penuh. Kostas Terzidis seorang arsitek sekaligus professor pengajar di Harvard University, menciptakan sebuah istilah baru, yaitu Algorithmic Architecture untuk keterlibatan komputer dalam desain arsitektur. Menurut Kostas Terzidis, Arsitektur Algoritmik adalah istilah yang diciptakan untuk menunjukkan penggunaan algoritma dalam arsitektur. Namun terdapat beberapa masalah seperti kompleksitas dan ketidakpastian, sehingga perlu solusi yang mungkin dibutuhkan untuk menciptakan hubungan sinergis antara pikiran manusia dan sistem komputer. Sinergi ini hanya mungkin melalui penggunaan strategi algoritmik yang menjamin hubungan antara pikiran manusia dan mesin. Arsitektur Algorithmik adalah suatu area penelitian yang mempelajari tentang aplikasi algoritma didalam arsitektur. Strategi algoritmik memanfaatkan pencarian pola yang berulang, prinsip-prinsip universal, modul yang dapat dipertukarkan, dan hubungan induktif. Kekuatan dari sebuah algoritma terletak pada kemampuannya untuk menyimpulkan dan untuk memperluas batas-batas tertentu dari pemikiran manusia.

Hubungan antara algoritma, parameter dan output dalam komputasi juga terdapat dalam arsitektur. Parameter dalam komputasi menyamai urutan yang merupakan sesuatu yang menciptakan metode dalam arsitektur. Dalam desain, algoritma dapat digunakan untuk memecahkan, mengatur, atau mengeksplorasi masalah dengan peningkatan visualisasi atau pengorganisasian kompleksitas. Algoritmik arsitektur melibatkan penggunaan program lunak untuk menghasilkan ruang dan bentuk dari aturan yang berbasis dan melekat dalam program-program arsitektur, tipologi, kode bangunan, dan bahasa itu sendiri. Desain algoritmik tidak menghilangkan perbedaan tapi menggabungkan kedua kompleksitas komputasi dan kreatifitas penggunaan computer (Mandey. 2012).

\section{ZEB (Zero Energy Building)}

Energi dan keberlanjutan alam adalah kunci dalam pengembangan lingkungan binaan yang disebut dengan arsitektur ini. Penggunaan energi yang tidak diperlukan adalah buah arsitektur yang tidak memerhatikan kondisi lingkungan (Idham, 2016). Zero Energy Building (ZEB) merupakan jawaban dari permasalahan tentang energi dan keberlanjutan. ZEB memproduksi energi terbarukan yang cukup untuk memenuhi kebutuhan konsumsi energinya. ZEB memangkas pengeluaran yang diakibatkan oleh konsumsi energi. Banyak manfaat keberlanjutan yang dapat diambil dari ZEB, seperti meminimalisir dampak lingkungan, biaya perawatan dan operasional, resiliensi yang lebih baik terhadap isu kelangkaan energi dan bencana alam. Mengurangi konsumsi energi dalam konstruksi bangunan baru atau renovasi dapat dicapai melalui berbagai cara, termasuk desain terintegrasi, desain bioklimatik, energy efficiency retrofits, dan program konservasi energi. Pengurangan konsumsi energi membuatnya lebih sederhana dan lebih murah untuk memenuhi kebutuhan energi bangunan dengan sumber energi terbarukan (Torcellini, et al. 2006).

\section{Biommimicry Architecture}

Memperhatikan hubungan antara ekologi dan arsitektur, yaitu hubungan antara massa bangunan dengan makhluk hidup yang ada disekitar lingkungannya, tak hanya manusia tetapi juga flora dan faunanya. Arsitektur sebagai sebuah benda yang dibuat oleh manusia harus mampu menunjang kehidupan dalam lingkugannya sehingga memberikan timbal balik yang menguntungkan untuk kedua pihak. Pendekatan ekologis dilakukan untuk menghemat dan mengurangi dampak-dampak negatif yang ditimbulkan dari terciptanya sebuah massa bangunan, akan tetapi dengan memanfaatkan lingkungan sekitar. Charles Jenks (1971) telah meramalkan perkembangan pesat pendekatan ekologis di tahun akhir di abad 20 pada bukunya yang berjudul Architecture 2000 Predictions and Methods.

Biomimikri merupakan sebuah metode perancangan produk maupun arsitektur yang pertama kali diperkenalkan oleh Janine M. Benyus (1997). Biomimikri merupakan cabang teknik biologis yang bergerak pada usaha untuk mencari struktur serta fungsi dari bentuk makhluk hidup 
untuk digunakan sebagai model dalam desain material dan mesin. (https://www.rumahku.com diakses pada 19/12/2018). Biomimikri juga dianggap sebagai pendekatan alternatif untuk keberlanjutan (Nkandu dan Alibaba. 2018). Kata 'Biomimicry' berasal dari 'bios' yang berarti kehidupan, dan 'mimesis' yang berarti meniru. Demikian pula, konsep ini mencakup juga terminologi seperti ' biomimetic ', biomimesis ', biognosis ' dan ' bionic ', digunakan dalam berbagai disiplin ilmu untuk studi dan penelitian untuk mengembangkan teknologi mutakhir dengan belajar dari alam. Biomimicry, yang dapat diterjemahkan sebagai ' mempelajari adaptasi alam dengan meniru mereka ', mulai dianggap sebagai ilmu baru dengan mewujudkan 'kemungkinan solusi dan solusi potensi dari alam' (Tavsan, C. Tavsan, F. and Sonmez, E. 2014).

Alam menghasilkan suatu bentukan alami yang dinamis dan bervariasi. Akan tetapi semua kebebasan bentuk di alam tersebut memiliki aturan masing-masing yang saling beradaptasi satu sama lain. Banyak yang sudah mengaplikasikannya dalam arsitektur, contohnya Beijing National Stadium yang meniru form sarang burung yang seakan tidak teratur, namun sebenarnya memiliki aturannya sendiri. Belajar dari aturan alam, manusia bisa mendapat sebuah bentuk yang bebas, namun tetap memiliki aturan(https://geometryarchitecture.wordpress.co m diakses pada 19/12/2018). Menurut Benyus, jika proses pembelajaran ini berlanjut dengan menyebar ke berbagai disiplin ilmu, ' sebuah revolusi biomimitric ' akan berlangsung dalam waktu dekat (Benyus, 1997).

\section{Intergalactic Architecture}

Untuk mengatasi kelangkaan lahan di masa depan, atau sebagai antisipasi akan terjadinya bencana besar yang dapat sewaktu-waktu melanda bumi, kebutuhan manusia untuk dapat tinggal di luar angkasa menjadi signifikan untuk dikaji lebih dalam. National Aeronautics and Space Administration (NASA) dan industri ruang angkasa mulai berlomba untuk menempatkan orang di Mars. Sejumlah penelitian, survey, dan pengambilan sampel seperti operasi Viking hingga Mars Orbiter Lander telah dilakukan untuk mengetahui karakteristik dari planet Mars itu sendiri (Matousek, et al. 1998). Namun sementara itu arsitek dan desainer industri lebih dulu melihat ke depan untuk bagaimana manusia hidup ketika sampai di Mars.

Arsitek dan desainer industri didorong untuk berpikir secara luas tentang bagaimana merancang sebuah habitat transit yang bisa memenuhi kebutuhan para astronot dan meningkatkan kesejahteraan mereka. Habitat itu dirancang untuk menggunakan ruang dengan cara seefisien mungkin, namun tetap menjadi lingkungan seperti di rumah untuk astronot saat kondisi stres dan melelahkan (https://economy.okezone.com diakses pada 19/12/2018). Contoh dari penemuan hasil riset kolaborasi multidisiplin ini adalah tentang konsep Hybrid architecture untuk eksplorasi ruang angkasa jangka panjang (Merril, et al. 2015); Konsep Integrated Hybrid Transportation Architecture untuk transportasi manusia di Mars dengan durasi yang lama (Merril RG, Chai PR, Qu M. 2016); Konsep Entry, Descent and Landing Architecture Study (EDLAS) (Ciancolo, Polsgrove. 2016, kemudian dilanjutkan oleh Polsgrove, et al. 2018).

\section{Cyber Architecture}

Di era informasi dan teknologi, manusia membutuhkan suatu media dimana dapat dengan bebas mengekspresikan diri dan melakukan pertukaran informasi antara manusia yang satu dengan yang lain. Jaringan komputer digunakan untuk membuat dunia paralel dan memfasilitasi komunikasi antar manusia melalui dasar teknologi yang disebut dengan "Computer Mediated Communication" - CMC. Istilah CMC merujuk pada suatu proses tempat manusia menciptakan, mengubah dan mempersepsikan informasi dengan menggunakan sistem telekomunikasi jaringan yang memfasilitasi terjadinya encoding, transmitting, dan decoding suatu pesan. Dengan demikian maka CMC dapat dijadikan wahana bagi pembentukan komunitas bersama. Dalam perspsektif ini, komputer merupakan sarana untuk masuk dalam jaringan cyber. Beragam kegiatan layaknya kegiatan sosial pada dunia riil dapat dilakukan pada interaksi melalui CMC hanya saja 
mereka meninggalkan dunia fisik. Interaksi melalui CMC menciptakan sebuah lingkungan binaan baru, yaitu ruang alternatif baru bagi interaksi sosial manusia.

Aktivitas sosial melalui CMC melibatkan berbagai konteks komunikasi, baik yang bersifat personal, kelompok ataupun massa. Sebagaimana kehidupan ruang nyata, para pengguna CMC berinteraksi, bertransaksi, mendiami suatu alamat dan bersosialisasi dalam ruang maya yang dikenal dengan cyberspace. Pada awalnya kehidupan maya berasal dari fantasi manusia tentang realitas dunia yang lebih maju, sebuah hiper-realitas manusia tentang nilai, citra, dan makna kehidupan manusia sebagai simbol pembebasan (escaping) manusia akan kekuatan materi dan alam semesta (Bungin, 2006). Dan ketika teknologi memungkinkan semua itu, maka terbentuklah ruang baru bagi manusia di dalam dunia hiper realitas (hyperreality). Dari definisi dan deskripsi yang ada, dapat disimpulkan bahwa ruang-ruang berdimensi komputer memiliki arti yang sama dengan cyberspace dan ruang internet ketika diakses melalui teknologi; dan muatan (content) yang ada mengacu pada data, informasi, diskusi, ekspresi dan perasaan-perasaan yang timbul dalam diskusi yang terjadi sesama anggota. Dunia maya merupakan bentukan alternatif ruang sosial di samping dunia nyata. Di dalamnya terbangun interaksi dengan beragam bentuk dan tujuan yang dibangun oleh mereka yang menghidupinya. Pertukaran makna, penciptaan identitas, aktivitas wacana, pertemanan dan penciptaan nilai-nilai tertentu, layaknya di dunia nyata. Singkatnya, terdapat banyak kemiripan bentuk interaksi yang tedapat di duni maya dengan realitas nyata keseharian (Prasetyo. 2010).

\section{PENUTUP}

\section{Simpulan}

Buah karya dari arsitektur adalah evolusi lingkungan binaan. Manusia selalu menghadapi perubahan di lingkungan binaan mereka baik menuju ke arah yang lebih positif ataupun negatif (Idham, 2016). Perubahan ke arah yang positif dapat terjadi apabila manusia mampu kembali berdamai dengan alam. Seperti pada awal keberadaan manusia di dunia, ketika manusia bertempat tinggal dekat dengan alam, mereka berinteraksi seimbang dan harmoni dengan alam karena mereka memahami hubungan satu sama lainnya. Namun sayangnya, kecenderungan perubahan ke arah yang negatif nampak lebih mendekati kenyataan. Setelah manusia berkembang baik dalam jumlah maupun pengetahuan, sikap mereka menjadi berubah pada lingkungan mereka yang disebabkan dari cara untuk melindungi diri dari cuaca buruk dan musuh. Seiring dengan manusia yang semakin jauh dari asal-usul mereka, mereka membangun ruang hidup yang asing dari sebelumnya (Senosiain, 2003). Penaklukan alam oleh manusia menjadi tak terelakkan, sehingga manusia sendiri kian menjadi musuh alam (Idham, 2016).

Kualitas kehidupan manusia berangsurangsur mengalami kemerosotan secara struktural. Kelebihan penduduk dan teknologi industri telah menjadi penyebab terjadinya degradasi hebat pada lingkungan alam yang sepenuhnya menjadi ketergantungan hidup manusia. Kemerosotan kualitas lingkungan alam telah dibarengi dengan meningkatnya masalah kesehatan bagi masingmasing individu. Untuk memahami krisis yang multisegi, manusia perlu mengambil pandangan yang sangat luas dan memandang situasi ini dalam konteks evolusi budaya manusia. Orang-orang Cina, yang selalu memiliki suatu pandangan dunia yang benar-benar dinamis dan suatu pengertian sejarah yang tajam, tampak menyadari sepenuhnya adanya hubungan yang kuat antara krisis dan perubahan. Istilah yang mereka gunakan untuk "krisis" _wei-ji_ terdiri dari huruf-huruf yang berarti "bahaya" dan "kesempatan" (Capra, 2002). Hal yang dibutuhkan untuk suatu perubahan ke arah yang positif adalah refleksi diri, pengakuan adalah sebuah cara untuk melihat diri sendiri dan berdamai dengan masa lalu, kesadaran bahwa segala perilakunya memberikan dampak atau hubungan dengan konteks di sekitarnya, kemudian kesadaran untuk melakukan perubahan melalui pengetahuan yang dapat membuat dunia menjadi lebih baik (Lucas, 2016).

Kemajuan ilmu pengetahuan telah menggeser paradigma superioritas manusia. Ilmu pengetahuan menyadarkan manusia bahwa dunia tempat manusia tinggal tidaklah berbentuk bulat. 
Tidak sesederhana itu. Dunia kini dipahami dengan bentuk yang bisa berbeda-beda menurut ilmu pengetahuan. Bisa berbentuk fluida, string, gelombang, 9 dimensi, dan banyak bentuk lainnya seperti yang mencoba diungkapkan oleh teori-teori fisika modern yang sedang berkembang seperti teori dawai (Veneziano. 1960. dalamhttps://www.physicsoftheuniverse.com/topi cs_bigbang_superstrings.html diakses pada 14/02/2020) M-theory, superstring theory (Schwarz. 2000), loop quantum gravity (Rovelli, C. 2011), dsb. Jika teori-teori ini semakin mendapatkan pencerahan di masa mendatang, maka lingkungan binaan tempat manusia tinggal di dalamnya pasti juga akan mengalami perubahan yang sangat kompleks dengan cakupan yang jauh lebih luas, dan dimungkinkan hingga pengkondisian keberadaan dunia alternatif / dunia paralel.

\section{DAFTAR PUSTAKA}

\section{Buku}

Benyus, JM. 1997. Biomimicry Innovation Inspired by Nature. New York: Harper Perennial.

Capra, F. 2002. Titik Balik Peradaban. Yogyakarta: Bentang Budaya.

Gideon, S. 1982. Space, Time, and Arsitecture, Cambridge: Harvard University Press.

Idham, NC. 2016. Arsitektur dan Kenyamanan Termal. Yogyakarta: CV Andi Offset.

Jencks, C. 1960. The Language of Post-Modern Architecture. London: Academy Edition and New York: Rizzoli.

Jencks, C. 1971. Architecture 2000 Predictions and Methods. London: Studio Vista.

Lucas, R. 2016. Research Methods for Architecture. London: Laurence King Publishing. Ltd.

Mangunwijaya, YB. 1992. Wastu Citra. Jakarta: PT Gramedia Pustaka Utama.

Schwarz, JH. 2000. Introduction to Superstring Theory. arXiv:hep-ex/0008017v1

Senosiain, J. 2003. Bio-Architecture. United Kingdom: Architectural Press.

Terzidis, K. 2006. Algorithmic Architecture. United States: Elsevier Ltd.
Rovelli, C. 2011. Zakopane Lectures On Loop Gravity. arXiv:1102.3660

\section{Jurnal dan Konferensi}

Ciancolo, AD. Polsgrove, TP. 2016. Human Mars Entry, Descent, and Landing Architecture Study Overview. https://ntrs.nasa.gov/search.jsp? $R=2016$ O011571. diakses pada 12/02/2020.

G. Suciu A. Et al. 2013. Smart Cities Built on Resilient Cloud Computing and Secure Internet of Things. 19th International Conference on Control Systems and Computer Science, Bucharest, Romania, 29-31 May 2013.

Kim, T-H. Ramos, C. and Mohammed, S. 2017. Smart City and IoT. Future Generation Computer Systems, Volume 76, 2017, Pages 159-162, ISSN 0167-739X.

Mandey, JC. 2012. Algorithmic Architecture. Daseng: Jurnal Arsitektur • May 2012.

Matousek, A. et al. 1998. A Few Good Rocks: The Mars Sample Return Mission Architecture. AIAAIAAS Astrodynamics Specialist Conference. Boston, MA.

Merril RG, Chai PR, Qu M. 2016. Integrated Hybrid Transportation Architecture. https://ntrs.nasa.gov/search.jsp?R=20160 006318. diakses pada 12/02/2020.

Merril RG. Et al. 2015. Mars Conjunction Crewed Missions with a Reusable Hybrid Architecture

https://ntrs.nasa.gov/search.jsp?R=20150 009466 diakses pada 12/02/2020.

Nkandu, MI. Alibaba, HZ. 2018. Biomimicry as an Alternative Approach to Sustainability. Architecture Research 2018, 8(1): 1-11

Plageras, AP. Et al. 2017. Efficient IoT-based sensor BIG Data collection-processing and analysis in Smart Buildings. Future Generation Computer Systems . https://doi.org/10.1016/j.future.2017.09.0 82

Polsgrove, TP, et al. 2018. Human Mars Entry, Descent and Landing Architecture Study: Rigid Decelerators https://ntrs.nasa.gov/search.jsp?R=20180 $\underline{006608}$ diakses pada 12/02/2020 
Prasetyo, H. 2010. Cyber Community. Cyber Cultures: Arsitektur Sosial Baru Masyarakat Modern.

Tavsan, C. Tavsan, F. and Sonmez, E. 2014. Biomimicry in Architectural Design Education.4th World Conference On Educational Technology Researches, WCETR- 2014. Procedia - Social and Behavioral Sciences 182 ( 2015 ) 489 496.

Torcellini, P. et al. 2006. Zero Energy Buildings: A Critical Look at the Definition. National Renewable Energy Laboratory. Conference Paper. NREL/CP-550-39833. Volkov, AA. Batov, EI. 2015. Dynamic extension of Building Information Model for "smart" buildings. Procedia Engineering 111 ( 2015 ) 849 - 852.

\section{Media Elektronik}

https://economy.okezone.com diakses pada $19 / 12 / 2018$

http://ft.uajy.ac.id diakses pada 16/12/2018

https://geometryarchitecture.wordpress.com diakses pada 19/12/2018

https://science.howstuffworks.com diakses pada $20 / 12 / 2018$

https://www.physicsoftheuniverse.com/topics_big bang_superstrings.html diakses pada $14 / 02 / 2020$

https://www.rumahku.com diakses pada $19 / 12 / 2018$ 